\title{
Theoretical and Practical Approach to the Lifelong Learning Paradigm: Creating Additional Vocational Training Program
}

\author{
Ekaterina A. Galperina*, \\ Elena Y. Nadezhdina and Yulia I. Shtogrina \\ National Research Tomsk State University \\ 36 Lenin, Tomsk, 634050, Russia
}

Received 14.07.2015, received in revised form 17.08.2015, accepted 16.09.2015

\begin{abstract}
This article points out the relevance of educational conception of the paradigm of Lifelong Learning in Russian system of education. The authors pay close attention to the conception of federal program in developing education for 2016-2020, which was fundamental in creating additional vocational training program «English for special purposes in the sphere of business and innovation», realized on the base of the International Department of Management by the National Research Tomsk State University and with the support from the European Union project 544283-TEMPUS-1-2013-1-ES-TEMPUS-JPHES "Lifelong Language Learning University Centre Network for New Career Opportunities and Personal Development". The article describes the pilot additional vocational training program as an attempt to raise the investment in people and knowledge; promote the acquisition of basic skills, develop people's employability and adaptability and broaden opportunities in the sphere of business and innovation.
\end{abstract}

Keywords: Life Long learning, a program of additional vocational training, English in the sphere of business and innovation.

The article is written with the financial support of the European Commission within the Tempus IV programme (Project "Lifelong Language Learning University Centre Network for New Career Opportunities and Personal Development (UNICO)”, № 544283-TEMPUS-1-2013-1-ES-TEMPUSJPHES).

DOI: 10.17516/1997-1370-2015-8-11-2291-2298.

Research area: pedagogy.

\section{Introduction}

Education plays a principally new role in modern world. Today the ideology of Lifelong learning (further LLL) paradigm determines the educational world politics. In the context of a changing society the educational system proved to be capable, on the one hand, of adapting to rapid transformations of new realities and on the other hand, to the phase of prolonged evolutionary reformation of the educational system which is especially important for Russian education in via to the integration into world educational space. The idea of "learning through the whole life" is of considerable interest for educators since the

(C) Siberian Federal University. All rights reserved

* Corresponding author E-mail address: kate.galp@mail.ru 
verge of the 20-21st centuries. LLL approaches refers to an individual's opportunity to acquire knowledge, qualifications and skills throughout his or her life, as well as the capacity to have his/ her prior learning recognized (whether personal, civic, social, professional or employmentbased learning). LLL must be exemplified by a universal right to LLL based on a set of training schemes open to a wide range of learners. This broad definition means a shift in perspective for all education system players. In a particular situation, the special attention is paying to adult education, providing human mobility on labor market independently of people's age.

According to statistical yearbook "Education in the Russian Federation: 2007" 22.4 percent of adult learners is included into the LLL based learning. Although the accuracy of this figure is questionable for several reasons:

1. In national report at KONFITEA VI claims another data. It is said that all education forms of adults are contained about 30 percent of Russia population.

2. All figures that are relevant to our country excluding formal education are two times lower then European ones and leave-off from the leading group in three-four times. Appeal to the Methodological comments touching on the topic of "Lifelong education" revealed that in European countries presented data from Eurostat -2003 (http://epp.eurostat.ec.europa.eu), and in Russia research data "Lifelong education" held by Higher School of Economics in 2006, therefore, the gap is even more serious.

3. Classification of education forms is not the same as in Eorostat. Clearly the allocation of additional professional education, a significant amount of which is certified and in accordance with our legislation, completed the issuance of public documents should be referred to the formal and self-education - to informal. But the self-education in our country is treated as a non-formal individual training, which, in contrast to the formal and supplementary education is not certified by a diploma or any other document.

In our opinion, the attempt to resolve the aforementioned disagreement is the decree approving the concept of the federal target program of educational development for the years 2016-2020 (The concept...,2015). It will be implemented within the integrated projects for the creation and implementation of the new structure of higher education institutions, as well as upgraded technology of distance education. The aim of the concept is to "provide conditions for effective development of the Russian education, the formation of competitive human capital and increasing competitiveness of Russian education at all levels, including internationally."

The concept includes five main objects:

- the creation and distribution of structural and technological innovations in professional education, providing high mobility of the modern economy;

- development of modern mechanisms, contentand technology and supplementary education;

- implementation of measures to popularize scientific-educational and artistic activities among children and youth, identification of talented youth;

- creation of an infrastructure that provides conditions for education and training to the modern economy;

- the formation of popular education quality assessment system and educational outcomes.

The conception is envisaged the inclusion in the program of integrated projects for the creation and implementation of a new structure (model) of high schools, updating technology of distance education, the transition to a system 
of effective contracts with managers and teaching staff, the integration the strategy of development of the staff training system and the formation of applied qualifications, improving the system of quality assessment vocational training, attracting employers to participate in the managing of professional educational organizations.

\section{Implementation of the additional vocational training program}

An attempt to solve one of these problems in the framework of language education is a project of the European Union 544283-TEMPUS1-2013-1-ES-TEMPUS-JPHES "Lifelong Language Learning University Centre Network for New Career Opportunities and Personal Development" implemented by the authors on the basis of International Department of Management at National Research Tomsk State University. The project was developed and implemented a program of additional vocational training "English for professional purposes in the sphere of business and innovation" of 120 hours. The program contains professionally-oriented foreign-language material necessary for the formation of foreign language communicative competence in all types of speech activities and is aimed at improving communication skills useful for successful professional communication in a foreign language (English). The program involves immersion in a speech environment of English language, learning the official business and professional business oral and written communication, the formation of skills preparation and translation of documents, negotiations, meetings, discussions, press conferences and presentations in English, spontaneous communication in dialogic professional and business situations. The aim of the program is to train and improve cultural and professional competence in a foreign language and to acquire cross-cultural awareness skills. The program objectives are: 1) to develop English skills necessary for communicating in the target language environment; 2) to develop critical thinking skills essential in professional contexts; 3) to develop study skills which will enable efficient use and further improvement of Business English; 4) to develop confident learners and enhances professional cognitive processes and communication skills. The actuality of the program due to the urgent need to implement international and intercultural communication in a foreign language in specific professional, business, and scientific fields to strengthen economic connections through the integration of Russian business into the world's financial structures, to develop friendly relations among citizens of the Russian Federation with a population of foreign countries. The program has a modular structure; it reflects current trends in the linguistic professional education within the concept of LLL, namely:

- approach to learning as a process of reflecting on life and professional experience;

- emphasizing self-education with the teacher in the role of an organizer of the leaning process;

- modular structure of educational programs;

- wide use of new educational technologies, interactive forms of learning, project methods.

The program is designed for widespread use of modern means of training, the using of information and communication technologies to generate personalized learning paths. All classroom sessions are held in the classrooms equipped with audio, video and projective equipment. Incoming, current and final knowledge assessment is carried out by means of educational platform MOODLE. Upon 
mastering the program the student must have the following skills:

to know

- ethical and moral codes of behavior adopted in the foreign culture;

to be able to

- produce a logically structured report choosing the appropriate style for the audience (final presentation);

- identify the right way to systematize information, classify data, organize personal work with electronic resources;

to possess

- skills of expressing their thoughts and opinions in the interpersonal and business communication in a foreign language;

- a system of linguistic knowledge, including that of the basic phonetic, lexical, grammatical and word-formation phenomena

Conducting the survey

Before the training program all the students were asked to pass entrance test in order to obtain more information about the level of the language competence, to identify the expectations of the students and the subsequent adaptation of the material to the practical requirements of the audience. The testing and questioning involved 86 employees of different innovative business enterprises of Tomsk region. The following are the questions that were used for further analysis:

1. Do you consider knowledge of a foreign language to be a means of stimulating professional growth in the sphere of business and innovation? Give your reasons:

1. What are the htree main benefits to learning foreign language as a part of your professional development?

2. How would you describe your level of ability in the language you have studied (English)? Comment on your ability in the language you had studied at school (college, university).
a) I would have difficulty understanding anything
b) I can understand basic phrases
c) I can communicate in most situations
d) I can understand most spoken language
e) I am completely fluent

3. Would you like to discuss problems and situations related to your professional function in the course of language learning? Which are of the most interest/necessity to you?

4. Which patterns of work and modes of interaction do you feel most comfortable with?

a) Individual work

b) Pair and group work

c) Common discussion

d) Your own answer

5. What would encourage you to learn foreign language (English)?

a) Reading professional literature/ periodic

b) Watching movies/documentaries

c) Rope plays

d) Discussions

e) Your own answer

The language competence test consisted of 75 questions and includes three parts: grammar (40 questions), vocabulary (15 questions) and reading (15 questions). In each question you must choose only one correct answer. Testing time is 90 minutes. The language competence test was developed on the basis of on the educational platform Moodle. In addition, students were asked to answer a series of questions, allowing subsequently adjusted subject courses.

Analysis of the conducted survey reveled that the majority of respondents (86\%) view knowledge of a foreign language, namely the English language, as a big advantage in improving careers in the sphere of business and inovation, as it enables them to become better professionals and opens new perspectives in performing their professional duties. This result showed that 
employees have high potential motivation in learning a foreign language for their professional need.

The most demanded aspects of foreign language application were:

- conducting meetings, negotiations and presentations;

- making public speeches;

- contracting, discussing contracts and agreements details;

- professional interactions (resolving conflicts, reaching a consensus, planning cooperation, team building);

- work ethics.

Besides, most of the respondents mentioned professional vocabulary as a necessity for performing their work duties.

As for preferences in terms of patterns of communication and modes of interaction about $83 \%$ of participants chose group work as the most productive and comfortable. The most interesting aspects of language acquisition were discussions of profession-related problems and questions and role plays.

Analysis of language testing showed that most of the participants experience difficulties when choosing appropriate language means to perform the following functions:

- establishing personal contact, choosing situationally appropriate speech patterns;

- understanding and staying within certain styles of communication (formal, informal);

- expressing their ideas logically and coherently.

Having conducted the above described research, the authors of the project program were able to develop a program for employees in the sphere of business and innovation that contains professionally-oriented foreign-language materials necessary for the formation of foreign language communicative competence in all types of speech activities and aimed at improving the communication skills of employees necessary for successful professional functioning in a foreign language (English).The below mentioned template syllabus presents modules of the program in the sphere of business and innovation (see Table 1):

As a result, more than 50 employees of innovative companies in Tomsk and Tomsk region were trained in the 4 pilot groups (first three groups in spring 2015; one group are now studying). $89 \%$ of students indicated maximum proximity subject courses within their field of practice; the suitability of the results of the practical implementation, development and improvement of after graduation. The survey allowed students to evaluate and confirm the viability and relevance of creating such programs and to identify future prospects. As key learning outcomes, mentioned by the students after the successful completion of the program, were:

1. Their ability to express themselves in English;

2. Improvement of knowledge essential for Professional English (conducting meetings, negotiations and presentations, making public speeches discussing contracts and agreements details, work ethics and others);

3. Their ability to comprehend English grammar with the help of the sources and the materials of the program.

\section{Conclusion}

Hereby, the implementation of the additional vocational training program "English for professional purposes in the sphere of business and innovation" can be considered as successful attempt to realize the idea "It's never too late to learn" more specifically the paradigm of "Lifelong learning" in a real life. The program allows not only improving qualification, bringing ones skills up to date or retraining for a new line of work but also giving a chance for further personal 
Table 1. Template syllabus

\begin{tabular}{|c|c|}
\hline $\begin{array}{c}\text { № } \\
\Pi / \Pi\end{array}$ & Modules \\
\hline I & $\begin{array}{l}\text { Module } 1 \\
\text { Selection of personnel } \\
\text { Grammar: Tenses (Active voice), Word-building } \\
\text { Vocabulary: Recruiting. Interviewing. } \\
\text { Listening: The process of recruiting. } \\
\text { Speaking: Phrasal area: words and phrases at different stages of interweaving } \\
\text { Reading: Recruitment. The purpose of training and development. Firing employees. } \\
\text { Writing: Application letter. CV }\end{array}$ \\
\hline II & $\begin{array}{l}\text { Module } 2 \\
\text { Grammar: Past Tenses (Active voice/passive voice), Phrasal area } \\
\text { Vocabulary: Types of companies and ownership. Entrepreneurship. Corporate cultures. } \\
\text { Listening: Corporate structure. } \\
\text { Speaking: My Company: type of company. Office etiquette questionnaire. } \\
\text { Reading: "Monkey business?" }\end{array}$ \\
\hline III & $\begin{array}{l}\text { Module } 3 \\
\text { Effective Meetings } \\
\text { Grammar: Conditionals. Word-building } \\
\text { Vocabulary: Phrasal area: words and phrases at different stages of the meeting/negotiating } \\
\text { Listening: Preparing a meeting. Teleforum. Telephoning. } \\
\text { Speaking: Role-play "Meeting" } \\
\text { Reading: Tips for better meeting. } \\
\text { Writing: Agenda }\end{array}$ \\
\hline IV & $\begin{array}{l}\text { Module } 4 \\
\text { International Business Style } \\
\text { Grammar: Tenses (Passive voice) } \\
\text { Vocabulary: Phrasal area: formal and informal communication. } \\
\text { Listening: Cultural stereotypes. International business styles. } \\
\text { Speaking: Hospitality and informal contacts in international business } \\
\text { Reading: International business styles }\end{array}$ \\
\hline $\mathrm{V}$ & $\begin{array}{l}\text { Module } 5 \\
\text { Business correspondence } \\
\text { Grammar: Phrasal area: words and phrases for correspondence. Imperative mood. Prepositions of } \\
\text { place and time. } \\
\text { Vocabulary: Business correspondence: different types of letters } \\
\text { Writing: Structure of formal and informal letters }\end{array}$ \\
\hline VI & $\begin{array}{l}\text { Module } 6 \\
\text { Information systems and communication } \\
\text { Grammar: Phrasal verbs: Linking words and comparative construction } \\
\text { Vocabulary: Phrasal area: words and phrases for expressing preferences, giving reasons, making a } \\
\text { complaint about the situation, asking for colleagues' problems and giving advice. } \\
\text { Speaking: Information systems and communication: Media and Business } \\
\text { Review 1-6: Grammar and vocabulary test. } \\
\text { End of the course: Presentation }\end{array}$ \\
\hline
\end{tabular}

competitiveness increase as well as development and encouragement active citizenship and social inclusion. The program is a kind of preparation for a destabilized life of changing jobs, job requirements and geographical locations. In this vision of the nomadic worker, people must constantly adapt to new living conditions, technology and work requirements which develop, learning skills that help the individual to adjust to an ever changing world. 
Being a part of international project 544283-TEMPUS-1-2013-1-ES-TEMPUSJPHES "Lifelong Language Learning" University Centre Network for New Career Opportunities and Personal Development we are eager to:

- expand "Language Centre UNICO TEMPUS", created within the framework of the above mentioned project as one of the regional centers UNICO presented in six regions of the Siberian Federal District of the Russian Federation (Tomsk, Barnaul, Kemerovo, Novosibirsk, Krasnoyarsk and Chita) and Kyrgyzstan (Bishkek and Naryn), Tajikistan (Dushanbe);

- improve the interaction between regional UNICO centers which will be directed to the creation and distribution of structural and technological innovations in professional language further education, providing high mobility of professionals in the labor market;

- implement national strategies and policies on lifelong learning into new programs for citizens in order to increase in the number of people with professional or vocational qualifications in different age groups, and to increase in overall participation in lifelong learning in Tomsk region;

- use modern digital technology for learning and teaching effectively and efficiently;

- develop distance learning or e-learning, continuing education, homeschooling or correspondence courses.

\section{References}

The concept of the federal target program of education development for 2016-2020 URL: http:// government.ru/media/files/mlorxfXbbCk.pdf (date of treatment 08/17/2015)

The development and the state of affairs in the field of adult education // National Report of the Russian Federation. URL: http://www.unesco.org/es/confinteavi/national-reports/europe-and-northamerica, p. 2. (date of treatment $08 / 19 / 2015$ ) 


\title{
Теория и практика парадигмы образования \\ в течение всей жизни: \\ создание программы повышения квалификации
}

\author{
Е.А. Гальперина, \\ Е.Ю. Надеждина, Ю.И. Штогрина \\ Национальный исследовательский \\ Томский государственныій университет \\ Россия, 634050, Томск, пр. Ленина, 36
}

В статье рассматривается актуальность концепции обучения в течение всей жизни 6 российском образовании. Особое внимание авторы статьи уделяют концепции ФЦП развития образования на 2016-2020 годbl, которая стала основополагающей при создании программь дополнительного профессионального образования «Английский язык для профессиональных целей в сфере бизнеса и инноваций», реализуемой на базе международного факультета управления Начионального исследовательского томского государственного университета при поддержки проекта Европейского союза 544283-TEMPUS-1-2013-1-ES-TEMPUS-JPHES «Создание сети университетских языковых иентров для профессионального и личностного развития человека в рамках парадигмы образования в течение всей жизни. Авторы статьи детально описывают прочесс создания программы, способствующей приобретению новых знаний, формированию иноязычной языковой компетенции, и создание возможности для дальнейшего развития в сфере бизнеса и инноваций, а также результать обучения пилотных гpynn.

Ключевые слова: образование в течение всей жизни, программа дополнительного профессионального образования, английский в сфере бизнеса и инноваций.

Статья написана при финансовой поддержке гранта программы ТЕМПУС IV Европейского Союза (проект «Создание сети университетских языковых центров для профессионального и личностного развития человека в рамках парадигмы «образование в течение всей жизни», № 544283-TEMPUS-1-2013-1-ES-TEMPUS-JPHES).

Научная специальность: 13.00.00 - педагогические науки. 